\title{
ZASTUPLJENOST ŽENA U UPRAVLJAČKIM STRUKTURAMA ODABRANOG HRVATSKOG FARMACEUTSKOG PODUZEĆA
}

\begin{abstract}
Sažetak
U ovome radu govori se o stanju ravnopravnosti spolova u Republici Hrvatskoj te aktivnostima i mjerama koje se u tom području poduzimaju za smanjenje ili uklanjanje neravnomjerne zastupljenosti muškaraca i žena u upravljačkim strukturama. Cilj je rada prikazati izazove nerazmjerne zastupljenosti muškaraca i žena na rukovodećim pozicijama u europskim i hrvatskim poslovnim organizacijama. Ravnopravnost spolova predstavlja stratešku srž razvoja svih politika EU jer ni jedna država članica nije još postigla potpunu ravnopravnost. Zadnjih nekoliko dekada Europska je unija učinila značajan iskorak u smanjenju disproporcija kako bi se u praksi provelo načelo jednakosti spolova. Europska komisija želi da najmanje polovica žena bude u upravljačkim strukturama, ali će EU - ako se nastavi današnja dinamika - ostvariti ravnopravnost spolova tek za 60 godina! Svojim znanjima, vještinama i sposobnostima žene su postale ravnopravne kandidatkinje za članice upravljačkih struktura. Na međunarodnoj, regionalnoj i nacionalnoj razini poduzimaju se brojne mjere, donose strategije, planovi djelovanja, međunarodni ugovori, zakoni i drugi propisi, a s ciljem postizanja stvarne ravnopravnosti žena i muškaraca u svim područjima privatnog i javnog života. Istraživačka je hipoteza da u upravljačkim strukturama ravnopravnost spolova nije adekvatna.
\end{abstract}

Ključne riječi: indeks ravnopravnosti spolova, neravnopravan položaj žena u poduzećima, zastupljenost žena na rukovodećim pozicijama, prepreke za napredovanje žena u hijerarhiji

\section{Uvod}

Ravnopravnost spolova temeljno je načelo ljudskih prava te je nužan preduvjet za postizanje gospodarskog razvoja, socijalne jednakosti, zapošljavanja i napretka društva u cjelini. U ovome radu istražuje se zastupljenost žena u upravljačkim strukturama na različitim hijerarhijskim razinama u europskim i hrvatskim poduzećima. Provedbom Strategije za ravnopravnost žena i muškaraca u Europi 2020. - 2025., ravnopravnost spolova bit će utisnuta u srž razvoja svih politika EU. Naime, ni jedna država članica

Matej Perkov, mag. int. rel. et dipl., viši predavač na Visokoj školi Aspira, matej.perkov@aspira.hr 
još uvijek nije postigla potpunu ravnopravnost. Pomak je vrlo spor i još uvijek postoje razlike u zapošljavanju, plaći te na tržištu rada.

Empirijsko istraživanje obavljeno je u odabranom hrvatskom farmaceutskom poduzeću Medimar. ${ }^{1}$ U strukturi zaposlenika toga poduzeća $76 \%$ čine žene. Ovim je radom utvrđeno postoji li rodna neravnopravnost u vezi zapošljavanja, napredovanja, plaća i slično. Bez obzira na zakonodavstvo koje jamči rodnu ravnopravnost, još uvijek postoje razlike među spolovima. Isto tako, u teorijskom je dijelu istražena važnost upravljanja i rodne ravnopravnosti u upravljačkim strukturama. Statističkom je analizom analizirana rodna ravnopravnost na tržištu rada u zemljama Europske unije te je napravljena usporedba s promatranim poduzećem i s ostalim poduzećima na području Republike Hrvatske.

Cilj ovog rada bio je prikazati važnost ravnopravne zastupljenosti žena i muškaraca u upravljačkim strukturama poduzeća. Ukazuje se na probleme žena u poslovnom svijetu i na poduzimanje mjera kako bi se nejednakosti smanjile ili uklonile. $U$ radu su izdvojene brojne prepreke s kojima se žene susreću prilikom napredovanja u hijerarhiji. Svojim znanjima, vještinama i sposobnostima žene su postale ravnopravne kandidatkinje za članice upravljačkih struktura. Ipak, još uvijek svjedočimo nejednakosti spolova u većini poduzeća. Europska unija je potaknula zemlje članice i napravila značajan iskorak u posljednjih nekoliko desetaka godina u provođenju i unapređenju ravnopravnosti spolova. Muškarci su nekada imali glavnu ulogu u društvu i u poslovnom svijetu, ali napretkom društva uloga žene u potpunosti se mijenja. Poslovi koje su obavljale žene bili su manje vrednovani od onih koje su obavljali muškarci pa je ženama danas obrazovanje postalo iznimno važno. Istraživačka hipoteza je da ravnopravnost spolova u upravljačkim strukturama nije adekvatna. Rad bi trebao dati određeni doprinos hrvatskom fondu literature iz područja ravnopravnosti spolova u poslovnim organizacijama, boljem shvaćanju prepreka za napredovanje žena u hijerarhiji te rječniku i stručnoj terminologiji u okvirima teme.

\section{Pregled literature}

Uspostavljanje ravnopravnosti između spolova temeljno je načelo ljudskih prava i nužan preduvjet razvoja suvremenog društva. Današnje spoznaje o ovome području postoje još od početaka naše civilizacije. Od razdoblja prapovijesti ljudi su se okupljali s osnovnim ciljem zajedničkog preživljavanja. U takvim zajednicama postojala je jasna podjela rada prema spolu i dobi (Perkov, 2019: 3).

U povijesti su žene izostavljene kao sudionice u stvaranju i napretku civilizacije. Smatralo se da je sudjelovanje u javnim aktivnostima muška uloga, dok je briga oko

$\overline{1}$ Stvarno ime odabranog poduzeća radi povjerljivosti je fiktivno, ali su svi podaci i rezultati vjerodostojni. 
kućanstva ženska uloga. Žene su još od doba starog i srednjeg vijeka podnosile mnogobrojne zabrane, uključujući i elementarno pravo glasa. Francuskinje 1789. pokreću borbu za određena prava žena. U 19. stoljeću u Engleskoj za glasačka prava žena bori se pokret sufražetkinja. Sredinom tog stoljeća u Europi se ženama daje pravo da studiraju medicinu, ali samo iznimno kao partner liječniku muškog spola. Žene djelomično pravo glasa dobivaju tek nakon Drugog svjetskog rata, no muškarci su i dalje odlučivali o njihovom radu i imovini. Ženama je sudjelovanje u politici i vlasti bilo nedostižno. Povijesno gledano, borba za prava žena i ravnopravnost među spolovima trajala je dugo. Donijela je mnoge pozitivne promjene, međutim žene i danas nailaze na diskriminaciju (http://povijest.net/2018/?p=1456).

Jednakost spolova najveća je vrednota te temeljno načelo jednakosti i jedno od najviših moralnih načela ustavnog poretka Republike Hrvatske. Zakonom o ravnopravnosti spolova iz 2017. definira se i uređuje način zaštite od diskriminacije na temelju spola i stvaranje jednakih mogućnosti za žene i muškarce u svim segmentima života (NN, 69/17). Također, ističu se jednaki položaj i mogućnosti za ostvarivanje svojih prava. Unatoč brojnim pozitivnim inicijativama i pokretima, još uvijek postoje različiti oblici diskriminacije nad ženama, a društvo kao takvo još uvijek ne pruža iste mogućnosti za oba spola (Kemeter i Bartol, 2015: 7). Prema stavku 2. članka 18. spomenutog Zakona, Ured za ravnopravnost spolova zadužen je za izradu i praćenje Nacionalne politike za promicanje ravnopravnosti spolova. Tome je dokumentu koji je za četverogodišnje razdoblje Hrvatski sabor usvojio 2011., cilj otklanjanje i sprečavanje diskriminacije nad ženama i uspostavljanje ravnopravnosti spolova.

Vrlo su važni propisi, mjere i aktivnosti koje u tom području kontinuirano donosi i poduzima EU. Pristupanje naše zemlje EU bilo je poticaj donošenju Zakona o ravnopravnosti spolova koji je usklađen sa zakonodavstvom EU (Veštić, 2017). Donošenje tog zakona te pristupanje i članstvo u EU rezultirali su izmjenama postojećih i donošenjem drugih propisa kojima se omogućuje ostvarivanje ravnopravnosti spolova. Od Republike Hrvatske će se i ubuduće zahtijevati unapređivanje vlastitog zakonodavstva radi usklađivanja s europskim standardima i standardima međunarodne zajednice, a kako bi se ostvarila ona razina ravnopravnosti spolova koja je ostvarena u nekim razvijenijim zemljama EU.

\subsection{Izazovi za napredovanje žena u poslovnom svijetu}

Žene se u poslovnom svijetu susreću s brojnim izazovima. Ti izazovi najčešće mogu biti prepreke, ukoliko se odnose na diskriminaciju, nedovoljno poticanje ženskog poduzetništva, organiziranje privatnog i poslovnog života te se zbog toga ponekad moraju puno više potruditi i odricati u odnosu na muškarce. Gulin (2019: 9) klasificira izazove i prepreke $\mathrm{u}$ četiri skupine: 
1. socijalni izazovi: nedostatak samopouzdanja, nedostatak motivacije i inspiracije, nedostatak odlučnosti, strah od neuspjeha, nedovoljna podrška bližnjih

2. obrazovanje: nedostatak potrebnih poduzetničkih vještina i kvalifikacija

3. okruženje: nestabilna državna financijska podrška i subvencija, negativni utjecaji medija, manjak pozitivnih poduzetničkih primjera, podzastupljenost žena u upravljačkim strukturama

4. financijski izazovi: nedostatak početnog kapitala i drugog izvora financiranja prilikom uvođenja u vlastito poslovanje, nejednakost u plaćama u odnosu na muške kolege.

Osim tih prepreka žene se susreću s „nevidljivim” fenomenom staklenog stopa. Stakleni strop (engl. glass ceiling) naziv je za vrstu diskriminacije, tj. za sprečavanje da kvalificirane i sposobne žene napreduju u poduzeću (Jergovski, 2010: 20). Postojanje staklenog stropa rezultat je različitih predrasuda i negativnog stava prema ženama. Kao stereotipi pri usporavanju napredovanja žena mogu se navesti npr. stavovi da žene nisu dovoljno poduzetne, da nisu jednako sposobne i uspješne kao muškarci, da nemaju potrebne osobine vođenja i slično (Jergovski, 2010: 20).

\subsection{Indeks ravnopravnosti spolova}

Kako bi se izmjerio točan postotak ravnopravnosti spolova, širom svijeta postavljeni su razni instrumenti. Potrebu za indeksom ravnopravnosti spolova prvobitno je iznijela Europska komisija u Planu za ravnopravnost žena i muškaraca 2006. - 2010. Europski institut za ravnopravnost spolova (EIGE) iz Vilniusa u Litvi informira širu javnost o istraživanjima, statističkim podacima i dobrim praksama u težnji za ravnopravnošću spolova u EU (EU, 2020a). Godine 2013. pokrenuli su Indeks ravnopravnosti spolova (Gender Equality Index) koji svake dvije godine pokazuje trendove i pokazatelje u području ravnopravnosti spolova u pojedinim zemljama EU. Taj indeks mjeri složeni koncept ravnopravnosti spolova i, na temelju okvira politike EU-a, tijekom vremena pomaže u praćenju napretka ravnopravnosti između spolova u svim zemljama EU. Zapravo, pokazuje koliko su EU i njezine zemlje članice udaljene od postizanja potpune ravnopravnosti spolova. Spomenuti indeks jedinstveni je mjerni instrument koji se sastoji od šest temeljnih domena i dviju sporednih poddomena (EIGE, 2020) koje opisujemo u nastavku.

Rad - domena prikazuje položaj žena i muškaraca na europskom tržištu rada. On mjeri ravnopravnost spolova na tržištu rada. Osnovni su pokazatelji trajanje radnog vijeka i kvaliteta rada, fleksibilnost radnog vremena, usavršavanje na radnom mjestu i slično.

Novac - domena istražuje neravnopravnost u okviru financijskih sredstava i ekonomske situacije između žena i muškaraca. Mjeri razlike u prihodima te rizik od siromaštva i raspodjelu prihoda. 
Znanje - domena prikazuje razlike između žena i muškaraca u okviru obrazovanja i usavršavanja. Ta domena mjeri razlike u postotku u obrazovanju, segregaciji i cjeloživotnom učenju.

Vrijeme - domena je usmjerena na usklađenost ekonomskih te društvenih aktivnosti. Mjeri se vrijeme za slobodne aktivnosti i na aktivnosti koje nisu plaćene, odnosno spolnu ravnopravnost $\mathrm{u}$ vremenu provedenom u brizi oko djece te poslovima vezanim za kućanstvo, ali također i u drugim aspektima života poput kulturnih ili drugih slobodnih aktivnosti.

Moć - domena istražuje u kojoj mjeri na ravnopravnost spolova može utjecati izostanak žena pri donošenju odluka. Ona mjeri zastupljenost žena i muškaraca u političkom, društvenom i poslovnom svijetu.

Zdravlje - domena je usmjerena na ravnopravnost u okviru zdravstvenog statusa i pristupa zdravstvenim institucijama. Mjere se razlike u pogledu zdravlja, očekivanog životnog vijeka, godina zdravog života, kao i razlike u ispunjavanju medicinskih potreba.

Indeks ravnopravnosti spolova iz 2020. pokazuje da će EU - ako nastavi današnjom dinamikom - ostvariti ravnopravnost spolova tek za 60 godina (EIGE, 2020). Republika Hrvatska kao članica EU nažalost ima jednu od najnižih stopa poduzetništva. Temelj ekonomskog osnaživanja žena vlasništvo je nad proizvodnim sredstvima, s obzirom na to da sredstva stvaraju prihode, omogućavaju pristup kapitalu i kreditima, jačaju sposobnost pojedinaca i kućanstava da se nose sa svim ekonomskim situacijama te služe za očuvanje bogatstva. Spomenuti indeks za Hrvatsku u 2020. iznosi 57,9 po čemu smo točno za 10 mjesta ispod prosjeka $\mathrm{EU}$, a iza nas je po tom pokazatelju sedam zemalja članica.

\subsection{Strategija za ravnopravnost žena i muškaraca u Europi 2020. - 2025.}

Europska komisija (EK) je 2020. za sljedećih pet godina donijela Strategiju za ravnopravnost žena i muškaraca. Uspoređujući društvo diljem svijeta, EU je na prvom mjestu u segmentu ravnopravnosti spolova te je posljednjih nekoliko desetaka godina znatno napredovala u tom području. Najvažnije mjere su načini pomoću kojih će se smanjiti nasilje i osigurati ravnopravne uvjete na tržištu rada, kao i jednaku zastupljenost u upravljačkim strukturama suvremenih poduzeća (EU, 2020b).

1. Čak 33 \% žena na području EU doživjelo je fizičko nasilje. U Strategiji se poziva na donošenje pravnih mjera za kriminalizaciju nasilja nad ženama. Konkretno, plan je Komisije da područja kaznenih djela proširi na razne oblike nasilja nad ženama te da se takav zakon uskladi u cijeloj EU.

2. Žene na području EU zarađuju u prosjeku $16 \%$ manje od muškaraca te i dalje nailaze na prepreke u nalaženju i zadržavanju posla. Ravnopravnost među spolovima jedno je od temeljnih načela za inovativno, konkurentno i uspješno 
europsko gospodarstvo. Što se tiče različitosti plaća, EK će pojačati provedbu standarda EU-a povezanih s ravnotežom privatnog i poslovnog života, kako bi svi imali jednake prilike za privatni i osobni razvoj.

3. Treća se mjera odnosi na postotak žena u strukturama upravljanja. Žene još uvijek i u najvećim poduzećima EU zauzimaju samo $8 \%$ u upravljačkoj strukturi. Da bi se ženama omogućio pristup tome, EK će zagovarati prihvaćanje prijedloga iz 2012. o ravnoteži spolova u upravama društava.

Očito je da su stereotipi i nejednakosti i dalje snažno prisutni. Fakultete završava veći postotak žena u odnosu na muškarce, a ipak one u prosjeku zarađuju manje dok su u upravljačkim strukturama u najvećim poduzećima u EU iznimno minorno zastupljene. Upravo će izbori za Europski parlament 2024. biti primjer drugima na koji način potaknuti žene da što više sudjeluju u politici. Uzmemo li u obzir demografska pitanja i potaknu li se žene da pronađu posao u sektorima u kojima nedostaje kvalificirane radne snage, poput tehnološkog sektora i sektora umjetne inteligencije, to će pozitivno utjecati na europsko gospodarstvo. Cilj je EK dostići da najmanje polovica žena bude u upravljačkim strukturama.

Prema Svjetskoj banci (WB), žene se u Hrvatskoj uspješno školuju na svim razinama, no završeno školovanje ne znači i višu razinu sudjelovanja žena na tržištu rada. Sudjelovanje žena na tržištu rada opada s dobi, što je vjerojatno posljedica dvaju čimbenika, odnosno tradicionalnih normi koje se odnose na obitelj te na poteškoće s kojima se žene suočavaju u dobi za rađanje kada traže posao ili se pokušavaju vratiti na posao nakon zasnivanja obitelji. Kućanskim poslovima i djeci najviše su i dalje posvećene žene. Nejednakost na tržištu rada proizlazi iz činjenice da žene često napuštaju plaćene poslove da bi mogle pružati skrb djeci ili starijim članovima obitelji. Istovremeno se na muškarce često stavlja veći pritisak da moraju privređivati za svoje obitelji (World Bank Group, 2019: 11).

\section{Nejednakost žena u upravljačkim strukturama}

Cilj je svakog modernog društva spriječiti neravnopravnost spolova te ukloniti moguće prepreke. Ravnopravnost između muškaraca i žena u poslovnom svijetu dovodi do stabilnog i uravnoteženog poslovanja koje ima mogućnosti opstanka na globalnoj razini. No, potrebno je još puno vremena da bi se shvatilo koliko žene imaju važnu ulogu u društvu i u poslovnom svijetu.

Na području EU pozicije u upravljačkim strukturama zauzima ukupno oko 9,4 milijuna ljudi, od čega je 6 milijuna muškaraca (64 \%), dok je žena 3,4 milijuna (36 \%). Uz to, žene čine tek nešto više od jedne četvrtine radnih mjesta (27 \%) u najvišim razinama upravljačkih struktura (izvršni direktori i uprava), dok su u 2018. na rukovodećim mjestima u najnižim razinama upravljačkih struktura (voditelji, team lide- 
ri) žene zauzimale tek $17 \%$. Drugim riječima, iako žene predstavljaju otprilike polovicu ukupno zaposlenih u EU, znatno su u neravnopravnijem položaju u odnosu na muškarce.

Kako vidimo na prikazu 1, najveći je udio žena u upravljačkim strukturama u EU u Latviji (56 \%), nakon čega slijede Bugarska i Estonija (po 49 \%). Iza tih zemalja su Poljska i Slovenija (po 47 \%), Mađarska (43 \%), Litva (42 \%), Švedska i Irska (po $40 \%$ ), Slovačka (37 \%), Velika Britanija (36 \%). U EU je prosječni udio žena u upravljačkim strukturama $36 \%$. Na tom prosjeku su Belgija, Francuska, Hrvatska, Portugal i Finska.

Prikaz 1. Udio žena i muškaraca u upravljačkim strukturama u zemljama EU (2018)

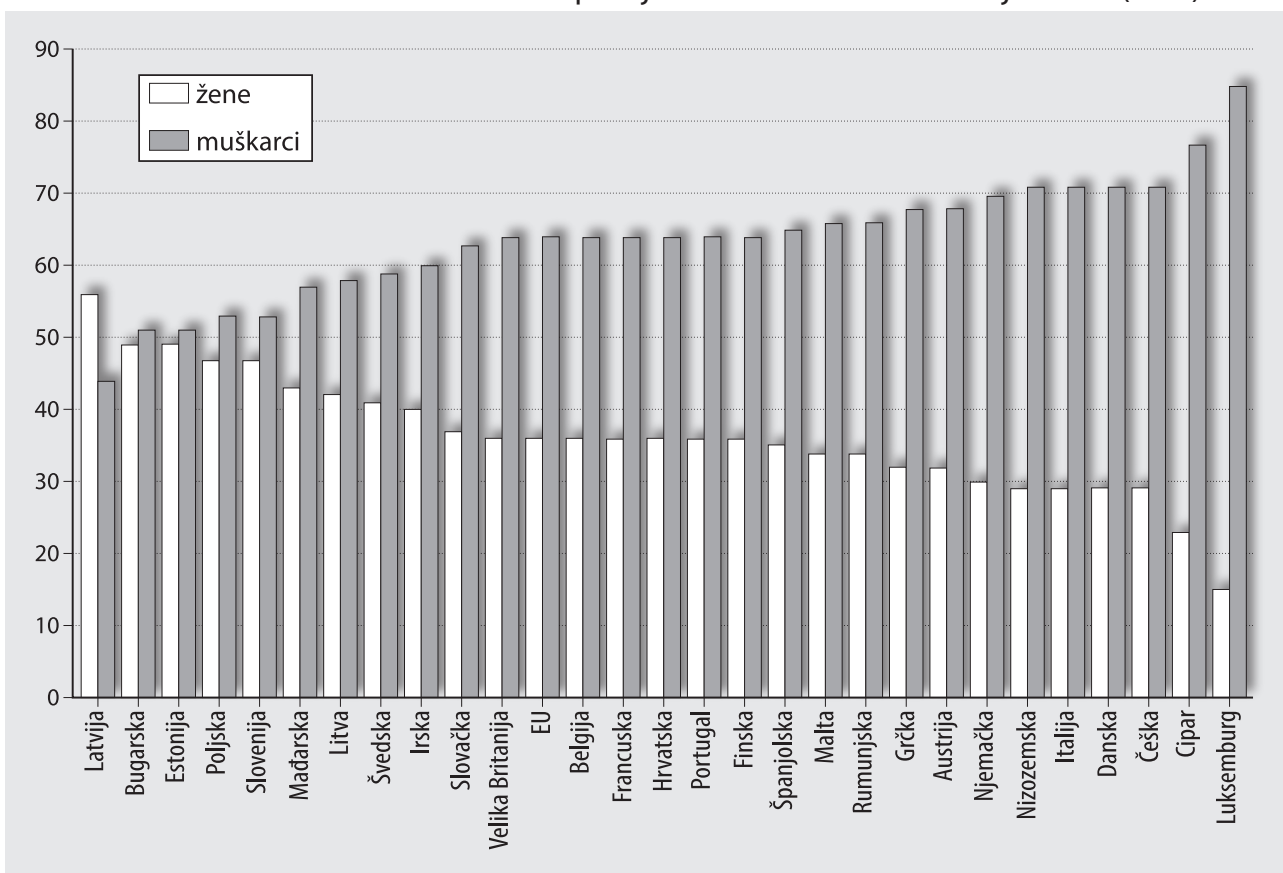

Izvor: obrada autora prema Eurostat (2020).

Nakon tih zemalja nešto zaostaju Španjolska (35 \%), Malta i Rumunjska (po 34 \%), Grčka i Austrija (po 32 \%), Njemačka (30 \%), Nizozemska, Italija, Danska i Češka (po $29 \%$ ), Cipar (23 \%) te Luksemburg (15\%).

U prikazu 2 nalaze se podaci o zastupljenosti muškaraca i žena u upravljačkim strukturama na području Republike Hrvatske u razdoblju 2015. do 2018. Očit je porast zaposlenih u upravljačkim strukturama tijekom promatranog razdoblja (za 6 tisuća). U upravljačkim je strukturama 2015. ukupno radilo 22800 zaposlenih, od kojih je samo 28,9 \% žena. Do 2018. udio žena u upravljačkim strukturama povećao se na $32,3 \%$, no muška populacija i dalje zauzima većinu, odnosno $67,7 \%$. 
Prikaz 2. Broj muškaraca i žena u upravljačkim strukturama u Republici Hrvatskoj (2015. - 2018.)

\begin{tabular}{rrrrcc} 
godina & žene & muškarci & ukupno & \multicolumn{2}{c}{ spolna raspodjela \% } \\
\hline 2015. & 6600 & 16200 & 22800 & 28,9 & Z \\
\hline 2016. & 9900 & 15600 & 25400 & 38,6 & 61,1 \\
\hline 2017. & 10200 & 18300 & 28400 & 35,6 & 64,4 \\
\hline 2018. & 9300 & 19500 & 28800 & 32,3 & 67,7 \\
& & & \multicolumn{3}{c}{ Izvor: obrada autora prema Eurostat (2020). }
\end{tabular}

Na prikazu 3 vidimo da je u 2018. zabilježen pad udjela žena od 0,3 \% u odnosu na prethodnu godinu. Jedan od mogućih uzroka tog smanjenja je migracija stanovništva Republike Hrvatske. Ukupan broj migriranih stanovnika u 2017. bio je 47 352, od čega je bilo $44,6 \%$ žena.

Prikaz 3. Kretanje žena i muškaraca u Republici Hrvatskoj u upravljačkim strukturama (2015. - 2018.)

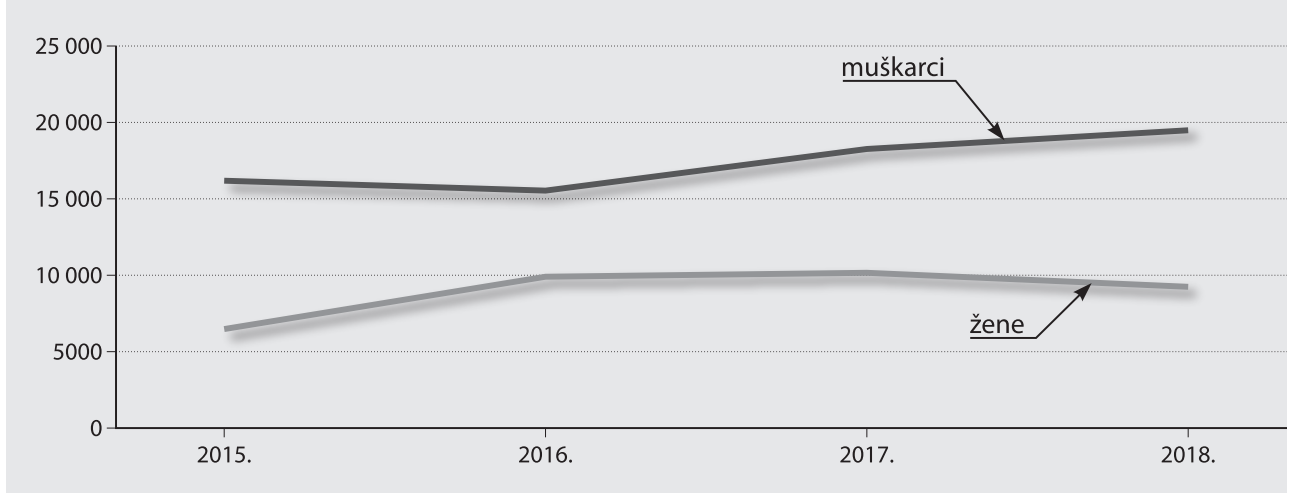

Izvor: obrada autora prema Eurostat (2020).

Recentno istraživanje Posarić et al. (2019) pokazuje da na nižim razinama upravljačkih struktura žene čine $34 \%$, na srednjim razinama $38 \%$, dok na višim upravljačkim strukturama žene zauzimaju samo $23 \%$ pozicija.

\section{Metode istraživanja i opis uzorka}

U ovome su radu podaci prikupljeni iz primarnih i sekundarnih izvora. Sekundarni izvori podataka su iz relevantne inozemne literature, znanstvenih i stručnih članaka te znanstvenih i stručnih bibliografskih baza. Tijekom obrade sekundarnih izvora i sukladno postavljenoj hipotezi, u radu se koristilo više znanstveno-istraživačkih metoda: metoda deskripcije (ponajviše iz strane literature), metode analize i sinteze te metode dedukcije i indukcije. 
Kako bi se ispunio cilj istraživanja, odnosno potvrdila ili demantirala postavljena hipoteza, u svibnju 2020. provedeno je primarno online anketiranje. Svrha istraživanja bila je prikazati važnost rodne ravnopravnosti u upravljačkoj strukturi odabranog poduzeća, odnosno ukazati na probleme žena u poslovnom svijetu i čimbenike koji utječu na njihovo napredovanje u organizacijskoj hijerarhiji. Pomoću odgovarajućeg upitnika u anketiranju je sudjelovalo 27 zaposlenika odabranog hrvatskog farmaceutskog poduzeća Medimar. To privatno poduzeće s osam povezanih društava u šest država djeluje već 20 godina, spada u velika (ima više od 500 zaposlenika i prihode od nekoliko stotina milijuna kuna), a više od 5 tisuća SKU-a plasira na 60 tržišta diljem svijeta.

Uzorak ispitanika činila su trojica muškaraca (11 \%) i 24 žene (89 \%). Upitnik se sastojao od 14 pitanja otvorenog i zatvorenog tipa. Prema dobi ispitanika, uzorak je bio strukturiran ovako:

- od 41 do 50 godina (45\% ispitanika)

- od 51 do 60 godina $(33 \%)$

- od 34 do 40 godina (22\%).

Anketni upitnik nisu ispunile osobe u dobi do 30 te starije od 60 godina. Obrazovna struktura uzorka bila je sljedeća:

- srednja stručna sprema (7 \% ispitanika)

- visoko stručno obrazovanje (74 \%)

- magistri znanosti (11\%)

- doktori znanosti zatim (8\%).

Prema poziciji u hijerarhiji odabranog poduzeća, struktura ispitanika bila je ovakva:

- visoka upravljačka razina - izvršni direktori (4\%)

- srednja upravljačka razina - direktori cjelina (22\%)

- niža upravljačka razina - vođe timova, nadglednici, koordinatori, voditelji i sl. (59\%)

- operativna upravljačka razina (15\%).

Prema radnom stažu u Medimaru, struktura ispitanika bila je:

- više od 20 godina (11 \%)

- od 16 do 20 godina (44\%)

- od 11 do 15 godina (30\%)

- od 7 do 10 godina (11\%)

- od 4 do 6 godina (4\%).

Zaposlenici s manje od četiri godine staža nisu sudjelovali u anketi. U nastavku je prikazano kako izgledaju omjeri kada je riječ o spolnoj ravnopravnosti, odnosno zastupljenosti žena na pojedinim upravljačkim razinama odabranog farmaceutskog poduzeća. 


\begin{tabular}{|ccc|}
\hline Razina upravljačke strukture & Žene (u \%) & Muškarci (u \%) \\
\hline niža & $70-80$ & $20-30$ \\
\hline srednja & $60-70$ & $30-40$ \\
\hline visoka & $20-30$ & $70-80$
\end{tabular}

\section{Rezultati istraživanja}

Na prikazu 4 vidi se da uvjerljiva većina, dakle $74 \%$ ispitanika, smatra kako su žene u odabranom poduzeću uglavnom ravnopravne s muškarcima. Nadalje, 19 \% njih smatra da su žene tek ponekad neravnopravne s muškarcima. K tome, 7 \% ispitanika izrijekom se izjasnilo da su žene u tom poduzeću većinom neravnopravne. Iz tih rezultata možemo zaključiti da je u Medimaru ipak prisutna relativna diskriminacija s obzirom na to da nitko nije dao nijedan odgovor koji bi sugerirao potpunu ravnopravnost muškaraca i žena ili povoljniji položaj žena.

Prikaz 4. Procjena zastupljenosti žena na upravljačkim pozicijama u Medimaru ( $\mathrm{N}=27)$

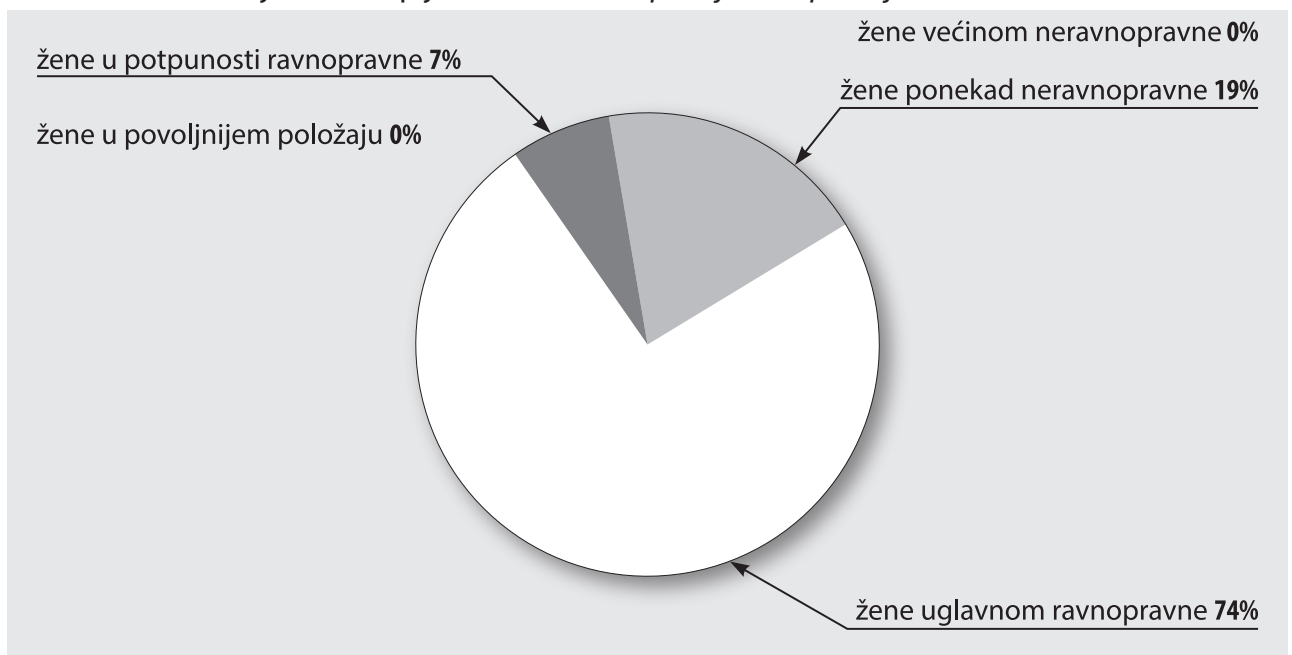

Izvor: autor.

Na kraju ovog dijela rada donosimo usporedbu rezultata našeg anketnog istraživanja s rezultatima iz istraživanja te teme u 239 odabranih poduzeća u Republici $\mathrm{Hr}$ vatskoj (Posarić et al., 2019). Usporedba se odnosi na udio muškaraca i žena na određenim razinama upravljačke strukture, a donosi se u prikazu 5.

Medimar je poduzeće u kojem žene čine udio od $76 \%$ od ukupno zaposlenih. Stoga je i daleko veća zastupljenost žena na nižoj (75 \%) i srednjoj razini (65 \%) upravljačke strukture u odnosu na prosjeke u hrvatskim poduzećima (34, odnosno $38 \%$ ). 
Kada je riječ o zastupljenosti žena na višim hijerarhijskim razinama, može se uočiti da je spolna struktura u Medimaru gotovo identična prosječnim vrijednostima u $239 \mathrm{hr}$ vatskih poduzeća. Prema već spomenutom istraživanju vidljivo je da su žene kod nas znatno manje zastupljene od muškaraca na svim trima upravljačkim razinama. To se posebno odnosi na više hijerarhijske strukture gdje ima manje od 1/5 žena (23\%).

Prikaz 5. Usporedba udjela žena i muškaraca u Medimaru s hrvatskim prosječnim vrijednostima

$\begin{array}{ccc}\begin{array}{c}\text { Razina upravljačke } \\ \text { strukture }\end{array} & \begin{array}{c}\text { Medimar } \\ (\mathrm{N}=27)\end{array} & \begin{array}{c}\text { Prosjeci između poduzeća } \\ \text { niža }\end{array} \\ \text { žene }-75 \% & \text { Žbublici Hrvatskoj }(\mathrm{N}=239) \\ \text { muškarci }-25 \% & \text { muškarci }-66 \% \\ \text { srednja } & \text { žene }-65 \% & \text { žene }-38 \% \\ & \text { muškarci }-35 \% & \text { muškarci }-62 \% \\ \text { viša } & \text { žene }-25 \% & \text { žene }-23 \% \\ & \text { muškarci }-75 \% & \text { muškarci }-77 \%\end{array}$

Izvor: autor i prema Posarić et al. (2019: 264).

Iz istraživanja autora proizlazi i da više od polovice (56 \%) ispitanika smatra da je omjer zastupljenosti žena i muškaraca u upravljačkoj strukturi Medimara adekvatan. Preostalih $44 \%$ njih smatra da bi postotak žena na rukovodećim pozicijama trebalo povećati. Od ispitanika se potom zatražilo da odaberu samo jedan (najvažniji) od osam ponuđenih razloga na kojima su temeljili svoj prethodni stav o zastupljenosti žena u upravljačkoj strukturi Medimara.

Prikaz 6. Temelji za stavove ispitanika o zastupljenosti žena u upravljačkim strukturama Medimara $(\mathrm{N}=27)$

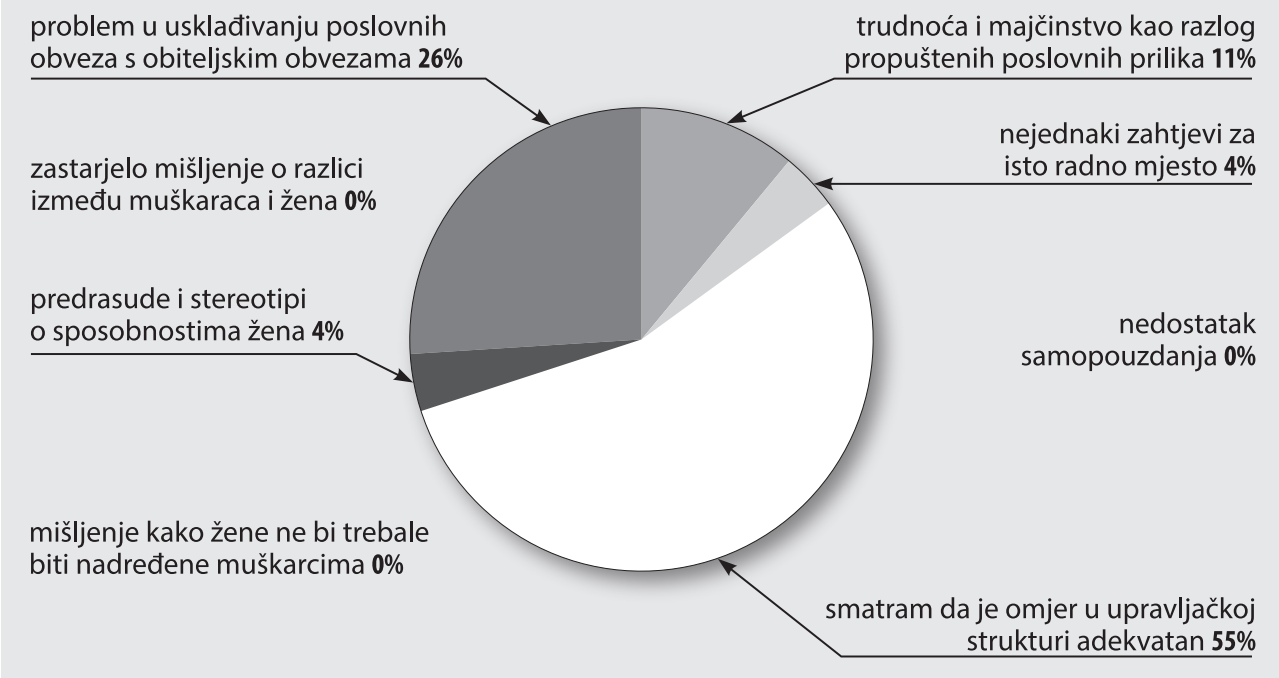

Izvor: autor. 
Prema prikazu 6, omjer zastupljenosti žena i muškaraca većina ispitanika (55 \%) smatra adekvatnim, tj. primjerenim u odabranom poduzeću (identično kao i kod prethodnog pitanja). No, među onima koji se s time ne slažu, $26 \%$ ispitanika smatra da je za napredovanje žena prema rukovodećim pozicijama temeljni problem usklađivanja poslovnih sobiteljskim obvezama. Nadalje, njih $11 \%$ svoj stav temelje na tezi da žene propuštaju poslovnu priliku zbog trudnoće i majčinstva. Tu je zapravo riječ o poznatom fenomenu staklenog stropa. I konačno, po $4 \%$ ispitanika stav temelje na predrasudama i stereotipima o sposobnostima žena, odnosno tezi da su nejednaki zahtjevi za isto radno mjesto. Preostala tri ponuđena odgovora za ovaj uzorak ispitanika očito su bili irelevantni.

U jednom od pitanja iz ankete, ispitanici su ocjenama od 1 (potpuno neslaganje) do 5 (potpuno slaganje) ocjenjivali stupanj suglasnosti s pojedinim tvrdnjama koje su se odnosile na položaj žena u odabranom poduzeću Medimar. U prikazu 7 vidi se zastupljenost odgovora za tvrdnju ženama nije lako napredovati iz ulaznih pozicija prema upravljačkim strukturama.

Iz prikaza 7 može se vidjeti da se $63 \%$ ispitanika slaže te se još $7 \%$ njih u potpunosti slaže s time da ženama iz ulaznih pozicija nije lako napredovati prema upravljačkim strukturama odabranog poduzeća. Samo $8 \%$ ispitanika se ne slaže s postavljenom tvrdnjom. Nitko nije iskazao potpuno neslaganje. S druge strane, čak $22 \%$ ispitanika nema nikakvo mišljenje. Proizlazi da žene moraju svladati teže prepreke, odnosno uložiti mnogo više htijenja i znanja od muškaraca da bi napredovale prema rukovodećim pozicijama u Medimaru.

Prikaz 7. Lakoća napredovanja žena prema upravljačkim struktura (N=27)

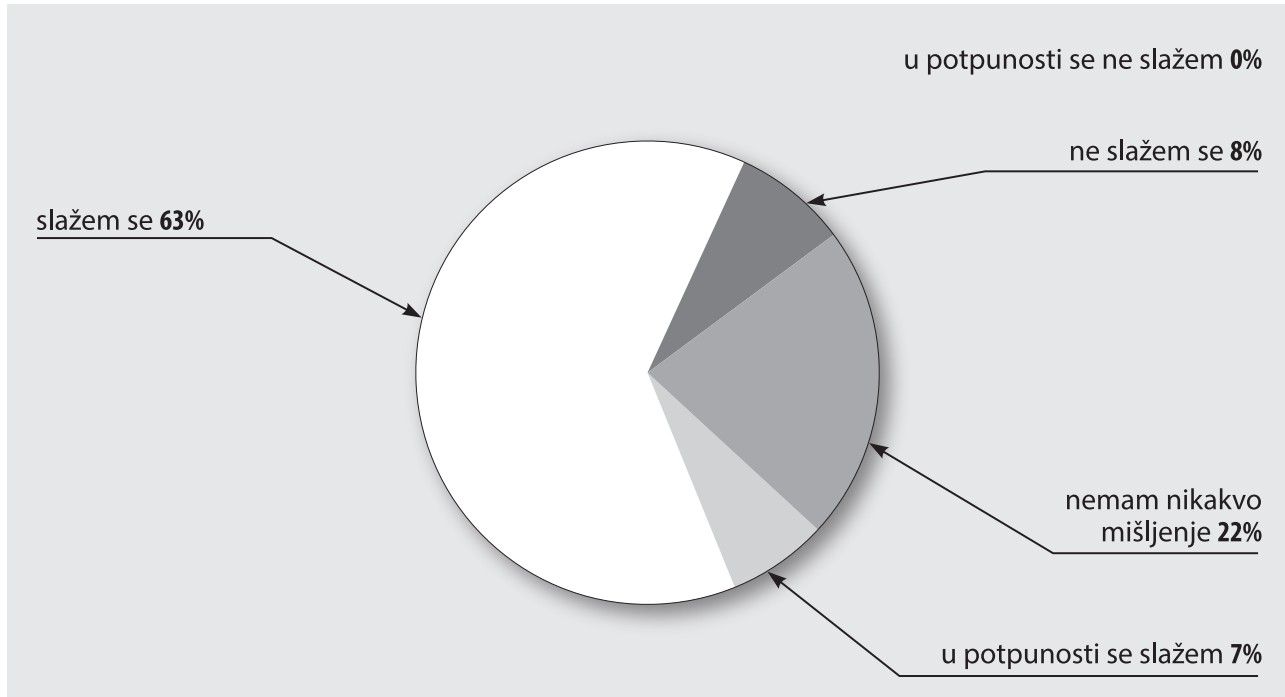

Izvor: autor. 


\section{Zaključak}

Cilj je ovoga rada bio istražiti razinu zastupljenosti žena i muškaraca u upravljačkim strukturama europskih i hrvatskih poduzeća. EU je na prvom mjestu po ravnopravnosti spolova i posljednjih je desetljeća evidentan znatan napredak u tom području. EU je 2020. donijela Strategiju za ravnopravnost spolova u kojoj su navedene i utvrđene ključne mjere koje se trebaju provesti do 2025. za prevladavanje neravnopravnosti između muškaraca i žena. No spolno uvjetovano nasilje i stereotipi i dalje su prisutni. Svaka treća žena u EU-u bila je žrtva fizičkog i/ili seksualnog nasilja. Iako fakultete završava više žena nego muškaraca, prema Indeksu ravnopravnosti spolova iz 2020. one zarađuju u prosjeku $16 \%$ manje nego muškarci, a žene su na samo $8 \%$ upravljačkih mjesta u najvećim poduzećima u EU. Iako je cilj Europske komisije da najmanje polovica žena bude u upravljačkim strukturama, EU će - ako nastavi današnjom dinamikom - ostvariti ravnopravnost spolova tek za 60 godina!

Recentna istraživanja pokazuju da na nižim razinama upravljačkih struktura žene u Republici Hrvatskoj čine $34 \%$, na srednjim razinama 38 \%, dok na višim upravljačkim strukturama žene zauzimaju samo $23 \%$ pozicija. U 2018. ukupni se udio žena u upravljačkim strukturama kod nas popeo na $32,3 \%$, što znači da muška populacija i dalje zauzima većinu, odnosno 67,7 \%. Iz empirijskog istraživanja može se uočiti da:

- 63 \% ispitanika se slaže te se još 7 \% njih u potpunosti slaže da ženama iz ulaznih pozicija nije lako napredovati prema upravljačkim strukturama odabranog poduzeća

- $26 \%$ ispitanika smatra da je za napredovanje žena prema rukovodećim pozicijama temeljni problem usklađivanje poslovnih s obiteljskim obvezama

- 11 \% ispitanika smatra da žene propuštaju poslovnu priliku zbog trudnoće i majčinstva, pri čemu je riječ o poznatom fenomenu staklenog stropa

- po $4 \%$ ispitanika smatra da je ženama teže napredovati zbog predrasuda $i$ stereotipa o sposobnostima žena, odnosno zbog nejednakih zahtjeva za isto radno mjesto.

Može se ustvrditi da je istraživačka hipoteza po kojoj u upravljačkim strukturama ravnopravnost između muškaraca i žena nije adekvatna - ovim radom potvrđena. Uvažavajući ograničenja koja deriviraju iz nedovoljno reprezentativnog uzorka ispitanika po broju (ukupno samo 27) i spolu ( 89 \% su bile žene), rezultate istraživanja valja uzeti više kao orijentaciju, a ne kao temelj za donošenje općih zaključaka o neravnopravnosti između spolova. Ipak, rezultati su dovoljno indikativni i vjerodostojni za dublje razumijevanje stanja i perspektiva o tom aktualnom aspektu suvremenog poslovanja. Konačno, istraživanje zaslužuje proširenje putem većeg uzorka u budućnosti kako bi se mogli iznaći snažniji i sveopći zaključci u tom području. 


\section{Literatura}

1. Gulin, S. 2019. Financiranje žena poduzetnica u Republici Hrvatskoj. Završni rad. Split: Ekonomski fakultet. https://urn:nbn:hr:124:524239.

2. Jergovski, A. 2010. Stakleni strop. Granice u napredovanju žena na ravnom mjestu. Obnovljeni život, 65 (3): 403-412.

3. Kemeter, D. i Bartol, B. 2015. Etika poslovanja kroz ravnopravnost spolova. Zbornik radova Međimurskog veleučilišta u Čakovcu. https://hrcak.srce.hr/140566.

4. Zakon o ravnopravnosti spolova. 2017. Narodne novine, 69/17.

5. Perkov, D. 2019. Upravljanje promjenama u poslovnoj organizaciji digitalnog doba. Zagreb: Narodne novine.

6. Posarić, N., Kokot, K. i Klačmer Čalopa, M. 2019. Analiza zastupljenosti žena na upravljačkim pozicijama u hrvatskim poduzećima i njihov utjecaj na uspješnost poslovanja. Ekonomski pregled, 70 (2): 259-275. https://hrcak.srce.hr/218815.

7. Veštić, S. 2017. Zakon o ravnopravnosti spolova - razlozi donošenja i institucionalni mehanizmi osiguranja provedbe. Zbornik radova Veleučilišta u Šibeniku, 3/4: 73-94.

8. DZS. 2019. https://www.dzs.hr/ 12. kolovoza 2020.

9. EU. 2020a. https://europa.eu/european-union/about-eu/agencies/eige_hr. 22. rujna 2020.

10. EU. 2020. https://ec.europa.eu/croatia/News/strategija_za_rodnu_ravnopravnost_teznja_za_unijom_ravnopravnosti_hr.22.rujna 2020.

11. EIGE. 2020. https://eige.europa.eu/gender-equality-index/2020/HR 22. listopada 2020.

12. Eurostat. 2020. https://ec.europa.eu/eurostat/home. 8. listopada 2020.

13. http://povijest.net/2018/?p=1456. 12. kolovoza 2020.

14. World Bank Group. 2019. Ulaganje u jednake mogućnosti za sve: Analiza rodne ravnopravnosti u Hrvatskoj. https://www.worldbank.org/ 28. listopada 2020. 


\section{Representation of women in the management structures of the selected Croatian pharmaceutical company \\ Abstract}

This paper discusses the state of gender equality in the Republic of Croatia and the activities and measures that are being taken to reduce or eliminate the unequal representation of men and women in governance structures. The aim of this paper was to present the challenges of disproportionate representation of men and women in management positions in European and Croatian business organizations. Gender equality is the strategic core of all EU policies, as no member state has yet achieved full equality. In the last few decades, the EU has taken a significant step towards reducing disparities in order to put the principle of gender equality into practice. The European Commission wants at least half of women to be in governing structures, but the EU - if today's dynamics continue - will achieve gender equality only in 60 years! With their knowledge, skills and abilities, women have become equal candidates for members of management structures. Numerous measures are taken at the international, regional, and national levels, strategies, action plans, international treaties, laws and other regulations are adopted, with the aim of achieving real equality between women and men, in all areas of private and public life. The research hypothesis is that gender equality is not adequate in management structures.

Key words: gender equality index, unequal position of women in companies, representation of women in management positions, obstacles to the advancement of women in the hierarchy 